\title{
Population Growth in New Hispanic Destinations
}

\author{
KENNETH M. JOHNSON AND DANIEL T. LICHTER
}

$\mathrm{T}$ The spread of America's Hispanic population has been a major source of new population growth in the United States outside traditional immigrant gateways, such as New York, Chicago, and Los Angeles. Much of the debate and conversation about Hispanic immigration has focused on immigration-induced population growth. Far less attention has been paid to the impact of Hispanic natural increase (more births than deaths). Natural increase is now the major engine of Hispanic population growth in both the core and suburbs of large metro areas, in many smaller metro areas, and in rural communities. The increasing importance of natural increase adds a new dimension to the challenge of integrating the growing Hispanic population into rural and urban areas. This brief provides a new demographic portrait of rural and small-town America, one now being redrawn by the infusion of Hispanic migrants and, perhaps more important, by the large number of Hispanic births in the United States.

Our analysis provides a glimpse of America's future. Current trends will remake the social and cultural fabric of communities for decades to come. ${ }^{1}$ They raise new concerns about ethnic conflict, flagging immigrant incorporation, and the burdens on local taxpayers (e.g., bilingual education, property taxes, health care, and social services). ${ }^{2}$

More important, the rapid rise in the Hispanic population in America is likely to continue, with or without restrictive immigration legislation. Through natural increase, Hispanic population growth has taken on a momentum of its own.

\section{Hispanics Now Account for Half of U.S. Population Growth}

The share of overall U.S. population gain attributable to Hispanics has grown rapidly over the past two decades. During the 1990s, for example, the U.S. population grew by 32.7 million persons-the largest population increase in U.S. history. Hispanics accounted for 13.3 million, or nearly 41 percent, of this population growth. The Hispanic population grew by 60.6 percent during the 1990 s, while the overall U.S. population grew by only 13 percent. Hispanic growth since 2000 has accelerated, and by July 2007 had already grown by 10.2 million. Even more remarkable, though Hispanics represented only 12.5 percent of the U.S. population in 2000, they produced one-half of the entire U.S. population increase between 2000 and 2007. As a result, Hispanics now constitute 15 percent of the population.

For many communities, Hispanic population growth often makes the difference between growth and decline. Indeed, between 2000 and 2005, an unprecedented 221 counties experienced population increases only because Hispanic gains more than offset population decline of non-Hispanics (Figure 1). Hispanic population gains also diminished the overall loss in another 1,100 counties, including large swatches of the Great Plains, where years of decline have threatened the region's economic and demographic viability. In another 1,600 counties, Hispanic population increase combined with gains among the non-Hispanics to accelerate population growth.

Figure 1: The Impact of Hispanic Population Change on Overall Population Change, 2000 to 2005

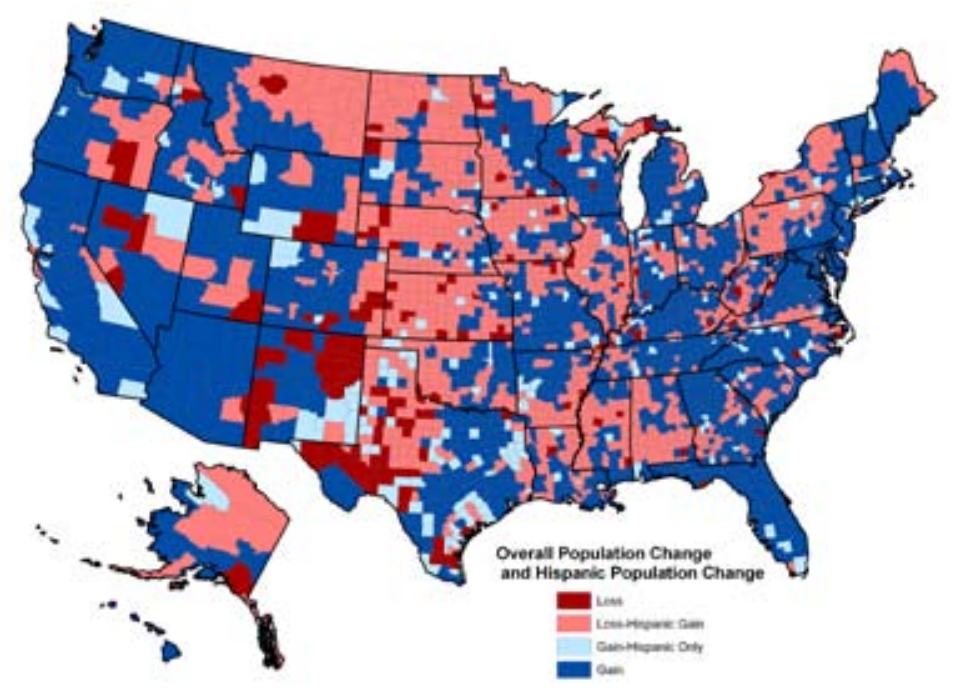

Data: Census 2000 and FSCPE 2007 
A Young Population Means Many Births and Few Deaths, Fueling Population Gains

Populations grow when more people move into an area than leave or when there are more births than deaths. In the case of Hispanics, these demographic processes are occurring simultaneously, producing remarkable Hispanic gains. To be sure, the initial impetus for the recent population surge was immigration-between 2000 and 2007, 4.2 million Hispanics immigrated to the United States, supplementing the $7.7 \mathrm{mil}-$ lion who arrived during the 1990s. Most of these immigrants were young adults on the cusp of parenthood, and many started families. The natural increase that resulted from this has now taken center stage in explaining Hispanic growth in the twenty-first century. Between 2000 and 2007, somewha more than one-half ( 58.6 percent) of the Hispanic population gain of 10.2 million was from natural increase. And, thi natural increase is accelerating.

The current Hispanic population gains result from a ver he 836 births. In rontrat For every Hispanic death, there is 1.37 biths for cory death. This pronounced difference reflects, amo for things a much younger Hisparc

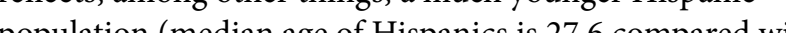
population (median age of Hispanics is 27.6 compared with panic women are of childbearing age (15-44) comparis with only 40.6 percent of non-Hispanic women Hispanic women also tend to have children earlier and they tend to have more children (2.8 children, on average, compared with 2.0 for all U.S. women in 2004). Adding to the impact of high fertility is a comparatively low death rate, among Hispanics, who are much younger than the native population.

The large demographic impact of Hispanics is perhaps best reflected in the demographic components that accou for overall U.S. population growth (not Hispanic growth alone). As shown in Figure 2, Hispanics accounted for 50.4 percent of the U.S. population gain between 2000 and 2007 yet they represented only 12.5 percent of the population in 200 . They cortibuted 52.8 percent of the pet migration gain (immigration) during the period and 49 percent of al the natural increase in the country.

The geographic reach of natural increase is broad an deep. In 251 counties (8.0 percent), natural increase is great enough to offset a Hispanic migration loss (Figure 3). has (Chicago) and Los Angles as wl a contes Southestern counties which have long ind as 作 such counties reflects the spatial dispersion of Hispan from traditionl gateways into the rural Midwest and South as well as to the urban fringe. In another 594 counties (18.9 percent), Hispanic growth is fueled primarily by natural 促e Migration remains the primary source of Hispanic growth in 1,386 counties (44.1 percent), though nearly all are experiencing natural increase as well. Some of these counties are places where Hispanic growth is recent, in others immigration is ongoing. In only 120 counties is the Hispanic popubeyond traditional gateways, there are still large spead country with few Hispanics. One fourth of US cous of the fewer than 200 Hispanics in 2005. Most of thes. counties are located in the northern and central Great Plains the Appalachians, and the interior Southeast.

Figure 2: Hispanic Percentage of US. Population AND DEMOGRAPHC CHANGE, 1990-2000 AND 2000-2007

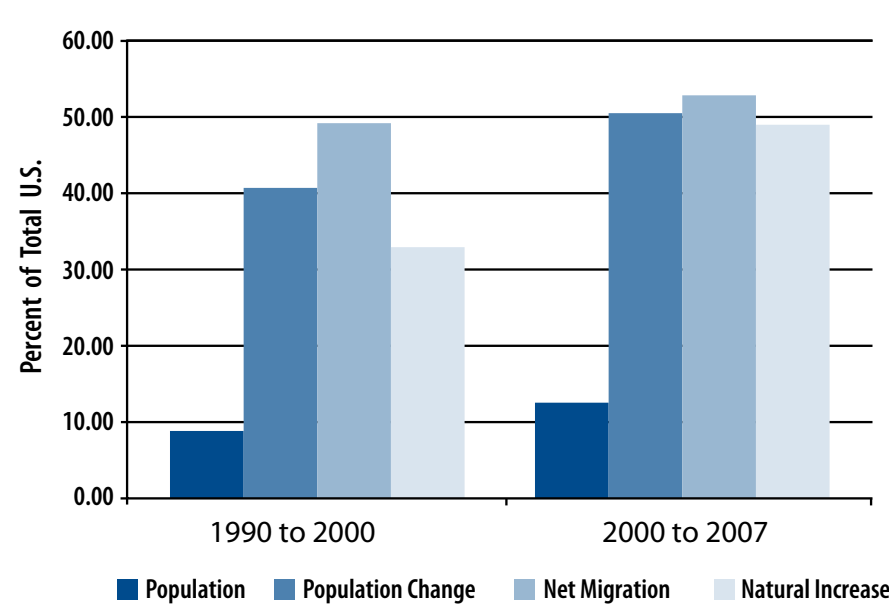
Source: 1990 and 2000 Census and 2007 Census Estimates

Figure 3: The Contribution of Natural InCrease to Hispanic Population Change, 2000 to 2005

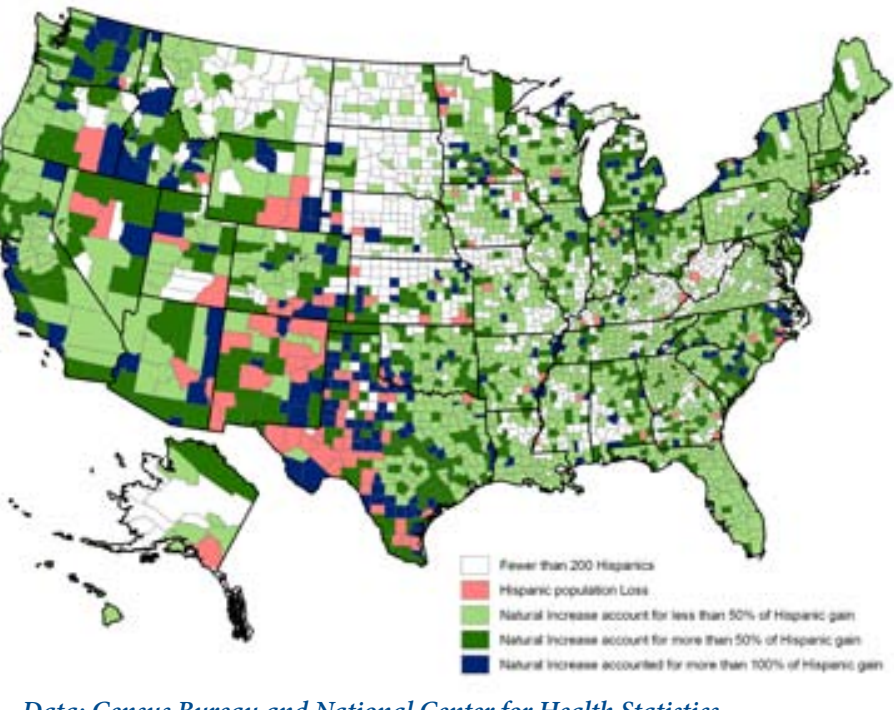

Data: Census Bureau and National Center for Health Statistics Analysis: K.M. Johnson, Carsey Institute, University of New
Hispanics Helped Stem

Population Loss in Rural Areas Hispanics are a major source of growth in rural America (see Figure 4). Between 2000 and 2005, Hispanics accounted for 45.5 percent of nonmetro population growth. The large demographic footprint belies the small size of the rural Hispanic population. Hispanics represented only 5.4 perce of the nonmetro population in $2000 .{ }^{3}$ Yet, they accounted for over half (53.4 percent) of all nonmetropolitan natural increase and 37.8 percent of the rural net migration gain between 2000 and 2005. For many rural communities, such Hispanic gains represent the first population growth in decades.

Figure 4: Hispanic Contribution to Population AND DEMOGRAPHIC CHANGE, 2000 TO 2005

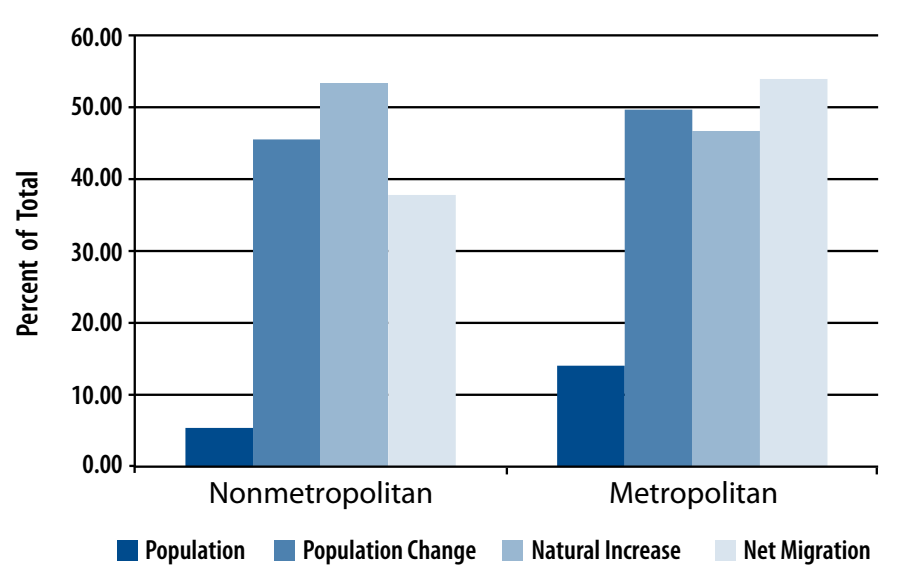
Source: 2000 Census and National Center for Health Statistis

During the 1990s, migration accounted for 57 percent of the overall Hispanic gain in metropolitan areas. In rura areas, migration was an even larger factor, accounting for 67 percent of the Hispanic population gain. ${ }^{4}$ The situation changed dramatically after 2000 , when natural increase became the main driver of growth. More than 58 percent of the nonmetro Hispanic increase and 55 percent of the metro Hispanic population since 2000 was fueled by natura

The impact of Hispanic population gains on rural communities has as much to do with the aging white populatrom with Hispanic high fertlity and low mortality. The tol graying pop more deaths than biths. Thes, increase together with migration is critical to the future of many rural areas.
Figure 5: Hispanic Population growth Patterns,

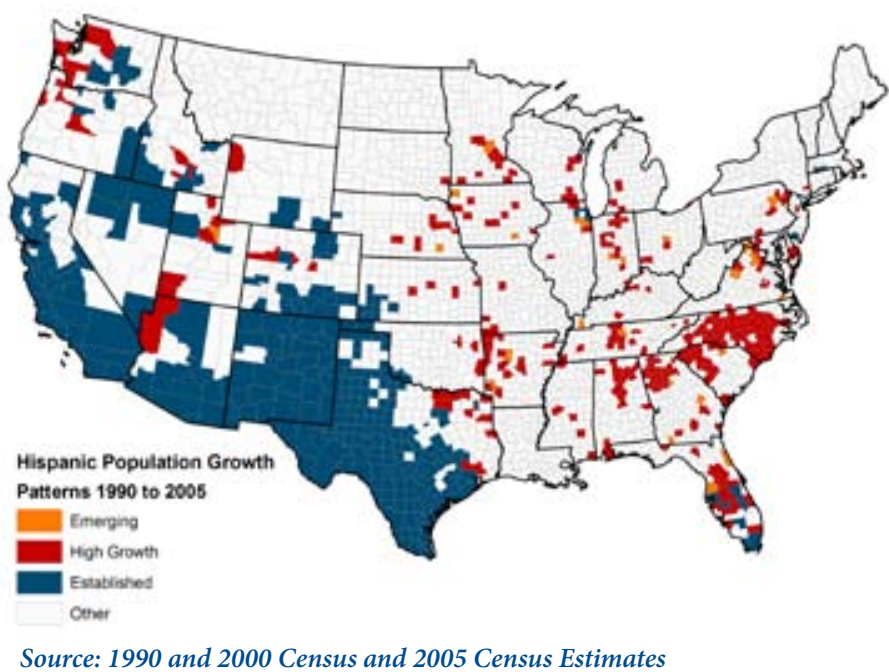

Hispanics are settling in new destinations

Hispanic growth in both rural and urban areas has been accompanied by a spreading of the population to new destinations. Not surprisingly, most nonmetro Hispanics (1.3 million) reside in the 205 established Hispanic countiescounties at least 10 percent Hispanic in both 1990 and 2000 (see Figure 5). ${ }^{5}$ However, 115 counties are Hispanic high growth counties-those with Hispanic population gains during the 1990s of at least 150 percent and with at least 1,000 Hispanics in the population. These counties were home to 359,000 Hispanic residents in 2000, some 13.6 percent of all nonmetro Hispanics. The newest destinations are the 13 emerging nonmetro Hispanic counties-those with at least a 75 percent Hispanic population increase between 2000 and 2005 and an absolute gain of at leas 500 Hispanics. An additional 945,000 reside in the other nonmetro counties.

The large majority of America's Hispanic population continues to reside in metro areas. Here Hispanics are heavly 74 percent of the 327 million urb Hins, which ics. The 178 high growth counties contain an addition 7.2 percent of urban Hispanics, and the 20 emerging Hispanic counties contain only 0.3 percent. The remainis 770 metro counties are home to 18.4 percent of urban Hispaniss. The increasing importance of natural increase for Hispanic growth means that Hispanics have gained demographic momentum. Both natural increase and migration have conmomentum. Both natural increase and migration have con-
tributed to Hispanic population growth in new destinations. The ascendancy of natural increase, not surprisingly, is most 

Figure 6: Percent of Hispanic Population Growth
Due to Natural Increase by Type and Metropolitan DUE TO NATURAL INCIEN
Status, 1990 TO 2005

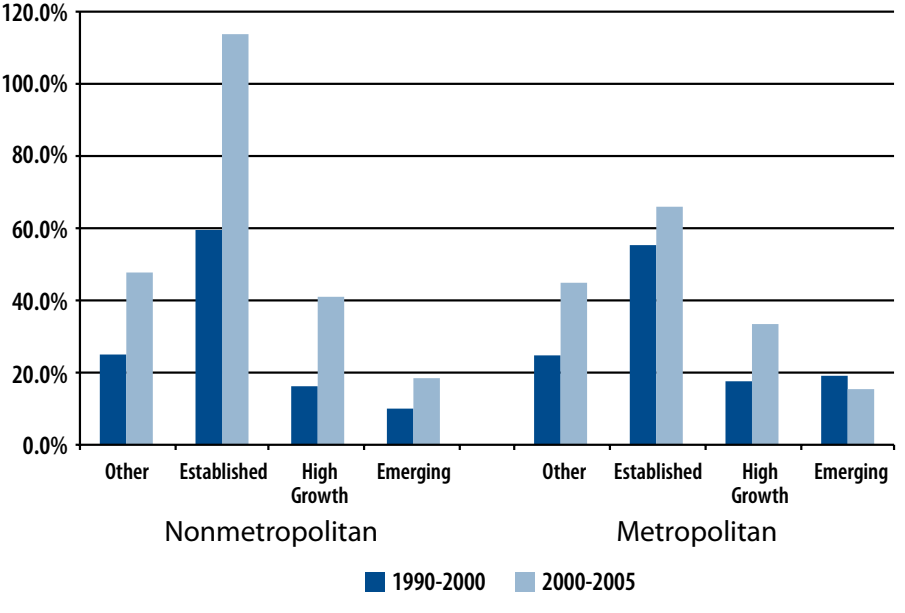

Source: Census Bureau and National Center for Health Statistics

evident in established Hispanic areas (see Figure 6), but it is spreading to high-growth counties that received sustained influxes of immigrants during the 1990s. In established Hispanic areas, for example, natural increase accounted for a growing majority of Hispanic population gain over the study period. In the other areas, the contribution of natur increase to Hispanic population growth accelerated from 25 percent of the gain in the 1950s to approximately 45 percent between 2000 and 2005. Even in the high grow th counties of the 1990s, the role of natural increase increased significantly after 2000

Hispanics are Here to Stay even without Continued Immigration Hispanic natural increase is a vital but often ignored component of population growth. Well over one-half of the recent Hispanic population growth was due to natural increase-compared with about one-third in the 1990s. Clearly, we are seeing a large secondary effect of past immigration in the form of high fertility and natural increase. The demographic implication is clear: Hispanic population growth is self-sustaining, even if mmigration were to be seriously curtailed through new restrictive legislation or by conomic downturn.

In a historical sense, the increasing importance of natura increase among immigrant populations is not wholly unexpected. Every immigrant group has gone through a similar migrants the the nasive-born popultion. The high ferily Irish immigrats in the nineteent century for exceeded rates of the ing nigant goups and cold not be explained by lower education or other social or economic conditions. ${ }^{6}$ Thus, the recent rise in Hispanic natural increase is not without precedent but few expected its impact would be felt so soon.

Hispanics are now playing an important role in the demographic and economic transformation of many communities. About one-half of the nonmetro Hispanic population now resides outside traditional Hispanic settlements in the rura Southwest. Moreover, a substantial and growing number of nonmetro counties experiencing non-Hispanic white population declines, especially in the Great Plains, have growing Hispanic populations. Hispanics clearly are a source of new demographic vigor in rural America. As we have shown here, more than 200 nonmetro counties - double the number observed for the $1990 \mathrm{~s}^{7}$ - would have experienced population decline between 2000 and 2005 without the substantial influx of new Hispanics and the natural population increase they spurred.

To be sure, Hispanics have revitalized many previously declining and economically stagnant small towns, but they have also brought serious and unprecedented challenges, including new demands for health care, bilingual education

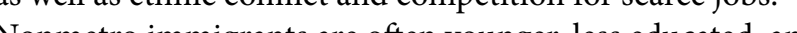
less likely to speak English the their couterparts in me areas ${ }^{8}$ Mny have arrived only recently which presents additional cultural challenges. New Hispanic immigrants are often highly segregated residentially and isolated from mainstream institutions. ${ }^{9}$ The political and administrative challenges (e.g., involving cash assistance or food stamps) are further complicated by the fact that Hispanic children are often U.S. citizens - most have been born in America - while their parents are foreign-born and often undocumented..$^{10}$ The policy implications associated with in-migration are clearly different from those associated with high fertility and natural increase. Natural increase and the growth of a new second generation in rural America reinforce the need to address questions about immigrant incorporation, education and language, and intergenerational economic mobility. This new demographic portrait provides a window to Americas future. Recent trends portend continuing growth that will shape the social fabric of many communities for decades to come. The ascendancy of Hispanic fertility and natural increase is unlikely to stall anytime soon. While many observers have lamented for decades the decline of small towns, today the most interesting and controversial responses. And now these debates are likely to cont much on high fertility as on immigration.

\section{Data and Methods}

The National Center for Health Statistics (NCHS) provided us with special tabulations of births and deaths by county by Hispanic origin." ${ }^{11}$ These data are supplemented with data from the Federal State Cooperative program (FSCPE), which provides population estimates, number of births and migration is estimated by subtracting the FSCPE estimate of immigration from net migration. We calculate population change by comparing data from the 2000 Census to the FSCPE estimate.

We calculated the demographic components of change between 1990 and 2000 following similar procedures, but we based them on 1990 and 2000 census-enumerated population rather than on population estimates. Data for the Hispanic population are fom the 1990 and 2000 censuses and from the 2005 and 2007 Census Bureau estimates of population by race/Hispanic origin.

We examine patterns of immigration and Hispanic poputhe 13 . 13 . Con as metro or nonmetro using the 2003 defition of the Office of Management and Budget Under this definition, metro areas are defined as those containing an urban core of 50,000 or more population. Metro areas include the county containing this urban core (or central city), along with any other counties that are highly integrated with the core county as measured by commuting patterns. There are 1,090 metro counties. The remaining 2,051 counties are classified as nonmetro. We use the terms metro and urban interchangeably as we do the terms nonmetro and rural. By convention, counties classified as nonmetro prior to the 2003 , but reclassified as metro by 2003 , are treated as metro throughout the analysis. ${ }^{14}$ 


\section{Endnotes}

${ }^{1}$ Leif Jensen, "New Immigrant Settlements in Rural America: Problems, Prospects and Policies." Reports on Carsey Institute University of New Hampshire Charles Hirschman and Douglas S. Massey "Places and Peoples: The New American Mosaic." In New Faces in New Places: The Changing Geography of American Immigration, edited by D. S. Massey (New York: Russell Sage Foundation, 2008), pp. 1-21.

${ }^{2}$ For more information on ethnic conflict, see Katherine Fennelly, "Prejudice toward Immigrants in the Midwest." In New Faces in New Places: The Changing Geography of American Immigration, edited by Douglas S. Massey (New York: Russell Sage Foundation, 2008), pp. 151178. For research on immigrant incorporation see Martha Crowley, Daniel T. Lichter, and Zhenchao Qian, "Beyond Gateway Cities: Economic Restructuring and Poverty among Mexican Immigrant Families and Children," Family Relations, vol. 55 (2006): 345-360.

${ }^{3}$ Hispanic population increases were not restricted to locations proximate to metropolitan areas. The overall nonmetro Hispanic population gain from 1990 to $2000 \mathrm{w}$ 65.7 percent. The gain was larger in nonmetro counties adjacent to a metropolitan area (73.4 percent) than in nonadjacent counties ( 54.2 percent). Hn all, nonmetro during the 1990s. The metro percentspe gin was slightly smaller the that in nonmetro ares (60.2 percent), althoug it was considerably larger in absolute terms at $12,272,000$. Between 2000 and 2005, the nonmetro Hispanic population grew by 18.9 percent adding another 497,000 popula with the gains in adjacent areas again exceeding those in nonadjacent counties. The metro population also continued to gain Hispanics, with a 21.1 percent gain of 6,885,000.
${ }^{4}$ Recent research suggests that some of the net Hispanic migration gain in rural areas also resulted from movement out of traditional Hispanic settlement areas in the Southwe and elsewhere. See, e.g.g., Daniel T. Lichter and Kenneth M. Johnson, "Emerging Rural Settlement Patterns and the Rural Sociology vol. 71 (2006): 109-131; Don to, Clo "Changing Faces, Changing Place: The Emaro Kawano, Nonmetropolitn Iming Tacs: "In New Faces in New Places: The Changing Geography of American Immigration, edited by Douglas S. Massey (New York: Russell Sage Foundation, 2008), pp. 75-98. The foreignborn population represents only 30 percent of the nonmetro Hispanic population, although a growing share of Hispanic migrants to rural areas appears to be arriving directly from Latin America. See William Kandel and John Cromartie, "New Patterns of Hispanic Settlement in Rural America." Rural Development Research Report no. 99 (Washington, DC: Economic Research Service, USDA, 2004).

${ }^{5}$ Ibid

${ }^{6}$ See Timothy W. Guinnane, Carolyn M. Moehling, and Cormac O'Grada, "The Fertility of the Irish in the United States in 1910," Explorations in Economic History, vol. 43, no. 3 (2006): 465-485. See also Jerry Wilcox, "Prolific Immigrants and Dwindling Natives? Fertility Patterns in Western Massachusetts, 1850 and 1880." Journal of Family

${ }^{7}$ For data on the 1990s, see Kandel and Cromartie, New Patterns of Hispanic Settlement (note 4 above).

Donato et al., "Changing Faces, Changing Places" (note 4 above).

${ }^{9}$ Daniel T. Lichter, Domenico Parisi, Steven M. Grice, and Michael C. Taquino, "National Estimates of Racial Segregation in Rural and Small-Town America," Demography, vol. 44 (2007): 563-581. See also John Iceland and Melissa Scopilliti, "Immigrant Residential Segregation in U.S. Metropolitan Areas, 1990-2000," Demography, vol. 45 (2008): 79-94.
${ }^{10}$ Mark Leach and Frank D. Bean, "The Structure and

Dynamics of Mexican Migration to New Destinations in the United States." In New Faces in New Places: The Changing Geography of American Immigration, edited by D. S. Massey (New York: Russell Sage Foundation, 2008), pp.

${ }^{11}$ We focused here on Hispanic data on births and deaths through 2005. In a small number of counties, NCHS suppressed lit number of Whanic biths and deaths for births and deaths to specific counties based on historical trends. This introduces a small but unknown degree of error in our estimates, but we are confident that at the level of aggregation at which we present our results, it has no material impact on our overall conclusions.

${ }^{12}$ We used a similar procedure to calculate the components of change for the Hispanic population, though it was not possible to disaggregate net migration into its domestic and immigration components.

${ }^{13}$ See Kenneth M. Johnson and Glenn V. Fuguitt, "Continuity and Change In Rural Migration Patterns, 1950 1995," Rural Sociology, vol. 65 (2000): 27-49.

${ }^{14} \mathrm{~A}$ similar practice is used for counties that were metro prior to 2003 but reverted to nonmetro status under the current definition. The overall effect of our decision to use the 2003 classification is to significantly reduce the number of counties included in the nonmetro group when compare with research using prior metro definitions. Using a fixed definition of nonmetropolitan and metropolitan removes longitudinal change. 


\section{A U T H OR S}

Kenneth M. Johnson is senior demographer at the Carsey Institute and professor in the sociology department at the University of New Hampshire. He can be reached at ken.johnson@unh.edu.

Daniel T. Lichter is director of the Bronfenbrenner Life Course Center and Ferris Family Professor in the Department of Policy Analysis and Management at Cornell University.

\section{A C K N OW LE D G E M E N T S}

This report is based on the authors' recent article titled, "Natural Increase: A New Source of Population Growth in Emerging Hispanic Destinations in the United States," which appeared in Population and Development Review 34(2): 327-346 (June 2008). The authors acknowledge the assistance of Robert Anderson and Stephanie Ventura at NCHS for providing unpublished data on Hispanic mortality and fertility. This research was supported by the W.K. Kellogg Foundation, Annie E. Casey Foundation and the Northern Research Station of the USDA Forest Service. The authors thank Sharon Sassler and Barbara Ray for helpful comments on an earlier draft of this paper. Allison Churilla of the Carsey Institute provided research assistance.

\section{UNIVERSITY an of NEW HAMPSHIRE}

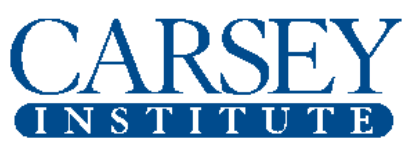

Building knowledge for families and communities

The Carsey Institute at the University of New Hampshire conducts independent, interdisciplinary research and communicates its findings to policymakers, practitioners and the general public.

Huddleston Hall

73 Main Street

Durham, NH 03824

(603) $862-2821$

www.carseyinstitute.unh.edu

The Carsey Institute Reports on Rural America are supported by the Annie E. Casey Foundation's initiative to strengthen rural families, the Ford Foundation, and by the W.K. Kellogg Foundation. 